\title{
Analysis of Fairness Limit on Fuel Oil Consumption of Two- Tail Test Based Excavator and Dump Truck A Case Study in PT FK
}

\author{
Bella Puspa Octaviani ${ }^{1}$, Supriyadi ${ }^{1}$, Ambran Hartono ${ }^{2, *}$
}

${ }^{1}$ Department of Mining Engineering, Faculty of Science and Technology Universitas Islam Negeri (UIN) Syarif Hidayatullah Jakarta Jl. Ir. H. Juanda No. 95 Ciputat Jakarta 15412, Indonesia

${ }^{2}$ Department of Physics, Faculty of Science and Technology, Universitas Islam Negeri (UIN) Syarif Hidayatullah Jakarta. Jl. Ir. H. Juanda No. 95 Ciputat Jakarta 15412, Indonesia

*Corresponding Author: ambran.hartono@uinjkt.ac.id

Article history

Received: 20-12-2019

Revised: 02-03-2020

Accepted: 20-03-2020

DOI: $10.31629 /$ jit.v1i1.2128

\begin{abstract}
A lack of method to find out the fairness limit of fuel consumption in mining operations enables statistical approach with two-tail test be applied to observe the fairness limit of actual fuel oil consumption compared to the manual handbook of its equipment. Fuel consumption according to the manual handbook for EXCA LIEBHERR 9350 excavator is 207.23 liters/hour and EXCA HITACHI 2500 is 191.51 liters/hour, while CATERPILLAR 777D Dump Truck is 36-53 liters/hour consider as low, 53-73, 8 liters/hour medium, and 73.8-96.5 liters/hour as high. This statistical approach has been carried out after fulfilling the concept of mechanized earth-moving. As a result, the differences in fuel consumption of LIEBHERR 9350 and HITACHI 2500 are $3.72 \%$ and $3.26 \%$, which are still in range of a reasonable fuel consumption limit, while CAT 777D operating on LIEBHERR 9350 and CAT 777D operating on HITACHI 2500 , each shows a difference in fuel consumption. The differences are $29.65 \%$, meaning that it has exceeded the reasonable limits of fuel consumption and $7.15 \%$, meaning that it is still in range of a reasonable fuel consumption limit.
\end{abstract}

Keywords: fuel consumption, two-tail Test, fairness limit and mining

\section{Introduction}

One of the major components in mining operation activities is the necessity of fuel oil as its consumption significantly affects the cost of mining operation, which is $30,26 \%$ [1]. This study focuses on fuel oil consumption of equipment for overburden removal activities.
Some aspects affecting on fuel oil consumption are condition of equipment, actual condition in the field, and the treatment of operator toward the equipment. Each mechanical equipment has its own specification of fuel oil consumption standard set by the company that makes that equipment. Evaluation on fuel oil consumption of these equipment will indicate whether or not the fuel oil consumption is still in 
the range of fairness limit. It will also prove the hypotheses that the fairness of consuming fuel oil is a must to come to a contract document.

\section{Theoretical Background}

The cost of fuel oil spent for equipment is not fixed (variable cost) in its execution (cost budgeting). However, it needs controlled as the amount of its nominal is more dominant and is likely to induce frauds. The cost of fuel oil allocated for overburden spends the most for dump truck, that is, $51.3 \%$ and for excavator, that is, $25.63 \%$ [1].

The concept applied is mechanical earth-moving one which is then to be tested statistically. Mechanical earth-moving is all kinds of works related to the activities of digging, loading and carrying, grading soil, laying foundation, removing dirt and rocks using mechanical earth-moving equipment. This concept pays more details on its mechanical equipment, cycle time, productivity, efficiency, match factor equipment, and others that affect the process of materials removing [2].

Relating to fuel oil consumption, the hourly consumption enables it to identify its effective working equipment. Besides, mechanical earthmoving concept also enables to find out the difference of fuel oil consumption among equipment and to arrive at its fuel ratio

Applying Mechanical Earth-Moving Concept

\subsection{Cycle Time}

a. Excavator

Cycle Time $=$ digging time + loading and swinging time + swinging time for the full bucket + swinging time for empty bucket....

b. Dump Truck

Cycle Time $=$ loading time + carrying time + dumping time + return time + directing time.

\subsection{Efficiency}

$\mathrm{E}=\frac{W_{e}}{W p} \times 100 \%$

Where:

We: Effective equipment working time

Wp: Available equipment working time

\subsection{Productivity}

a. Excavator equipment

$Q=\frac{q x E f f x 3600 x S F}{C t}$

Where:

Q = Productivity of equipment $(\mathrm{Bcm} /$ hour $)$

$\mathrm{q}=$ = Production per cycle

Eff $=$ Working Efficiency Correction Factor

$(\%)$

$\mathrm{Ct} \quad=$ Cycle Time $($ Second $)$

$\mathrm{SF} \quad=$ Swell Factor

b. Dump Truck

$Q=\frac{C x M x S F x E t x 60}{C t}$

$\mathrm{C}=\boldsymbol{q} \mathbf{1} \boldsymbol{x} \boldsymbol{n} x K$.

Where:

$\mathrm{Q} \quad=$ Productivity of dump truck (Bcm / hour)

$\mathrm{C}=$ Production per cycle or suited with bucket capacity

M = Number of operating dump truck

Et = Efficiency of working dump truck (\%)

$\mathrm{Ct}=$ Cycle Time (Minute)

$\mathrm{n} \quad=$ Number of cycle for filling dump truck

$\mathrm{q} 1=$ Capacity of Bucket Loader $\left(\mathrm{m}^{3}\right)$

$\mathrm{K}=$ Bucket Fill Factor

$\mathrm{SF} \quad=$ Swell Factor

\subsection{Match Equipment Factor}

$\boldsymbol{M F}=\frac{\text { NaxCTmxn }}{\text { CTaxNm }}$.

Where:

MF = Match Factor of heavy equipment

$\mathrm{Na} \quad=$ Number of carrying

$\mathrm{CTm}=$ Cycle time of carrying

$\mathrm{n} \quad=$ Amount of filling

$\mathrm{CTa}=$ Cycle time of loading

$\mathrm{Nm} \quad=$ Number of loading

\subsection{Statistical Approach}

Statistical approach is then conducted to test hypotheses and analyze egression. Hypotheses is intended to test any existing assumptions so as to draw conclusion and to make decision. While regression analysis is intended to measure any statistical relation among two or more variables. 
To determine the fair limit of fuel oil consumption of excavator equipment, Two Tail Test is applied to find out whether the difference between the actual fuel oil consumption and the manual handbook is significant enough or not [3]. Two tail test formulates its hypotheses, that:

a. $\mathrm{HO}=$ fuel oil consumption matches with manual handbook.

b. $\mathrm{H} 1 \neq \mathrm{H} 0=$ actual fuel oil consumption.

$\mathrm{H} 0$ is rejected if:

zo $<-$ p or zo $>+$ p. In contrast, H0 is accepted if:

$$
z_{0}=\frac{x-\mu_{0}}{\frac{x}{n}}
$$

For dump truck, it is to determine a more significant fuel oil consumption between grade road and hauling road. To get this result, analysis of regression is conducted. Its basic formula of simple linear regression is:

$\mathrm{Y}=\mathrm{a}+\mathrm{bx}$

Where:

$\mathrm{Y} \quad=$ bound variable

$\mathrm{X} \quad=$ free variable

A $\quad=$ intercept regression line

$\mathrm{B}=$ gradient regression line

$$
\mathrm{a}=\frac{(\Sigma \mathrm{y})\left(\sum \mathrm{x}^{2}\right)-(\Sigma \mathrm{x})(\Sigma \mathrm{xy})}{\mathrm{n}\left(\Sigma \mathrm{x}^{2}\right)-(\Sigma \mathrm{x})^{2}}
$$$$
\mathrm{b}=\underline{\mathrm{n}(\Sigma \mathrm{xy})-(\Sigma \mathrm{x})(\Sigma \mathrm{y})}
$$$$
\mathrm{n}\left(\Sigma \mathrm{x}^{2}\right)-(\Sigma \mathrm{x})^{2}
$$

\subsection{Calculating Fuel Oil Consumption}

Fuel oil consumption is the total consumption of each dump truck and excavator in one fleet in the volume of liter per hour. Fuel oil consumption is calculated in the following basic formula:

Fuel Oil Consumption $(\mathrm{FOC})=$

$$
\frac{\text { Total FOC }}{\text { Effective Working Hour }}
$$

The following formula is specially to calculate actual fuel oil consumption for excavator.
Fuel Oil Consumption (FOC):

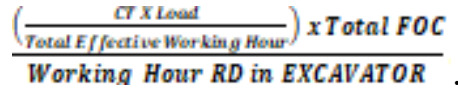

The following calculation of fuel oil consumption uses the approach of Cycle Time.

Low Consumption Category:

$\left(\frac{(L+D)}{(L+D+T)} \times 100 \%\right) \times$ Mean Value of Low Category

Medium Consumption Category:

$\left(\frac{(T)}{(L+D+T)} x 100 \%\right) x$ Mean Value of Medium Category

Fuel oil consumption using the approach of cycle time $=$ Low Consumption Category + Medium Consumption Category.

Where:

$\mathrm{L}=$ Loading time (Hour)

$\mathrm{D} \quad=$ Dumping time (Hour)

$\mathrm{T} \quad=$ Travelling time (Hour)

\subsection{Grade Road}

Grade road directly affects the capacity of the dump truck (be it in the matter of brake or grade). Grade road is usually in percentage (\%) and the basic formula to calculate grade road is:

Grade $=\frac{\Delta \boldsymbol{h}}{\boldsymbol{A} \boldsymbol{x}} \times 100 \%$

Where:

$\boldsymbol{\Delta} \boldsymbol{h}=$ Height difference

$\boldsymbol{\Delta x}=$ Distance

\subsection{Grade Resistance}

The value of Grade Resistance (GR) equals to the grade the equipment has to pass [4]. In other words, the higher the grade, the heavier the resistance, the more the power meaded to pass it. Each $1 \%$ grade higher will cause Grade Resistance for $20 \mathrm{lbs} /$ ton of heavy equipment. Hence, $1 \%$ grade requires power of $20 \mathrm{lbs}(9,1 \mathrm{~kg})$ to pull $1 \mathrm{~kg}$ weight of the dump truck. 


\subsection{Rim pull}

Rim pull is the amount of pulling power of the machine or the wheels of vehicle on the road. Rim pull is usually represented in the unit of weight unit, which is, $\mathrm{kg}$ or lbs. Rim pull relies on HP (Horse Power) and the speed of the vehicle. This template has been tailored for output on the custom paper size $(8.26 \mathrm{~cm} \times 11.22 \mathrm{~cm})$. The margins are set as follows: top $=0.98 \mathrm{~mm}$, bottom $=1.18 \mathrm{~mm}$, right $=0.79 \mathrm{~mm}$, left $=0.79 \mathrm{~mm}$, space between column $=0.3 \mathrm{~mm}$. The paragraphs must be indented. All paragraphs must be left justified and right justified.

\section{Methodology}

\subsection{Procedure}

a. Collecting cycle data from excavator and dump truck.

Cycle data from excavator and dump truck are collected from actual condition of excavator and dump truck were being observed and timed by using stopwatch. Collecting data were conducted as accurately as it can be.

Cycle data of excavator derives from the time it starts digging when the bucket touches the ground until the bucket is fully filled. Swing time starts when the loaded materials in the bucket are lifted by its arms toward the dump of the truck [5]. The loading process to the dump of the truck starts when the bucket pours all the materials into it. The returning time to the digging point starts when the bucket has fully poured all the materials and swings until the position of ripper bucket of the excavator touches the ground and starts digging again [5-6].

Cycle time for dump truck consists of maneuver time during empty dump truck + reversed time + loading time + dumping time as the parameter to count its fixed time. Hence, cycle time is fixed time + travelling time. Loading time starts when excavator is filling the dump truck until it is completely full and drives away. Travelling time of the loaded materials starts when the dump truck drives until it stops at the disposal point. Dumping time starts when the dump of the truck removes all the materials in it and back to the original position. Returning time starts when the dump truck drives and moves to the loading point [7]. b. Collecting data of actual fuel oil consumption.

The procedure is by observing excavator and dump truck filling their duel. Recording the amount of fuel consumption can be seen in the flow rate in the fuel truck system. Flow rate automatically records the fuel filled in the tank of the truck. However, a more accurate fuel-filling data is kept by the logistic department of Thiess Company as the contractor that is in charge of filling fuel for heavy equipment.

\section{c. Collecting data of grade road}

Data of grade road was collected based on daily haul profile sent by the contractor. The data from this haul profile shows the grade road condition. After getting the coordinate point of the grade road, a calculation was performed by sum product to get the grade road vehicles to use.

\section{Results and Discussion}

The actual fuel oil consumption for excavator and dump truck differs from what they refer to in their Mechanical Handbook as due to their higher consumptions. There are two factors to consider from its condition in the field, namely: factor of material and front-loading.

These are the two factors causing this difference; kinds of material and the condition of front-loading. Such conditions make the heavy equipment to consume more fuel oil than what is stated in mechanical handbook. The pattern of loading also plays important factor that causes higher fuel oil consumption for excavator, which is, Bottom Loading pattern. Hauling distance and grade road also affect fuel oil consumption. A more distant with higher grade road location causes fuel oil consumption increase.

The kind of material digged from blasting material is mudstone. The fragments of this blasting materials are still found large in their sizes. This condition makes the loading process has to break them beforehand they are loaded. This is the cause of higher fuel oil consumption.

After conducting statistical testing, it was found out that the different amount of fuel oil consumption between EXCA HITACHI 2500-1648 and EXCA LIEBHERR 9350-9003. The first one is $2,93 \%$, which is not significant enough. But it will be significant if it reaches $13,9 \%$. For the second one, the difference is $4,04 \%$, which is also not significant. It will be significant if it reaches $9,2 \%$.

The significant test on those two heavy equipment shows that their actual fuel oil consumption is still fairly normal. It is due to their amount of insignificant difference of fuel oil consumption which is identified in its ratio value 
test (z0) below acceptable zero hypotheses.

Less effective loading pattern will affect fuel oil consumption of the equipment. There are two loading patterns; top loading and bottom loading [9]. From the field observation, top loading pattern consumed less fuel oil than bottom loading. It is due to the longer swing time of bottom loading.

Fuel oil consumption of the equipment differs from the accepted standard. Fuel oil consumption of excavator RD on EXCA HITACHI 2500-1648 and RD on EXCA LIEBHERR 9350-9003 is higher than the standard one.

Actual fuel oil consumption of excavator RD on EXCA HITACHI 2500-1648 can be categorized into medium one, while the excavator $\mathrm{RD}$ on EXCA LIEBHERR 9350-9003 can be categorized into high one. One aspect that affects this is the grade road of hauling, in which Pit Lisat is higher than Pit Kinong. If the grade road elevates, its grade resistance is also higher, thus causing rim pull needs more power to move the loading material. This condition increases the need of fuel oil consumption, as on other results [8-10].

Grade resistance at Pit Kinong is $61,86 \mathrm{~kg}$, while at Pit Lisat is 79,1 kg. Rim pull needed by the dump truck at Pit Kinong is $11680,49 \mathrm{~kg}$, while at Pit Lisat is $12370,7 \mathrm{~kg}$. Therefore, the fuel oil consumption of dump truck operating with EXCA LIEBHERR 9350-9003 (at Pit Lisat) is higher than the one operating with EXCA HITACHI 25001648 (at Pit Kinong).

Haul road and grade road are two factors that affect fuel oil consumption of the dump truck [10]. Normally, the more distance of haul road and the grade road, the more fuel oil consumption needed. But the point is to find out which one of those two factors that affect more significant cause on fuel oil consumption for the dump truck.

It is found out that the relation between fuel oil consumption with grade road and haul road has more linear grade line, that is, $8.1 \%$, while the haul road is $0.04 \%$. As an effect, the grade of haul road is more significant than the distance of haul road. It is suggested that hauling at 1300 meter, the grade road is still ideal considering the fuel oil consumption of the dump truck (medium fuel oil consumption), that is, $7.5 \%$.

Both dump trucks operating at those two pits have different fuel oil consumption comparing with the standard one. RD on EXCA HITACHI 25001648 has different consumption for 9,36\%. Having been significantly tested, it was found out that it was not significant enough unless it reaches $17,5 \%$ and RD on EXCA LIEBHERR 9350-9003 happens to have different consumption for $21,81 \%$, as shown by the significant test.

\section{Conclusion}

Based on the extended statistical analysis applied to find out the fuel oil consumption for excavator, it was known that the actual fuel oil consumption for both equipment of EXCA HITACHI 2500-1648 and EXCA LIEBHERR 9350-9003) is still fairly normal. This is supported by the fact that the significant test indicates the difference of fuel oil consumption for both excavators was insignificant, in which, the value of significant test (zo) is within acceptable zero hypotheses (H0). Whereas, the actual consumption of RD on EXCA HITACHI 2500-1648 is also within fair limit, indicated by the value of significant test (zo) is within acceptable zero hypotheses (H0). For actual dump truck RD on EXCA LIEBHERR 9350-9003, it has exceeded fair limit of fuel oil consumption. The actual fuel oil consumption of dump truck RD on EXCA LIEBHERR 9350-9003 which has exceeded fair limit can be such inputs for the company to evaluate the fuel oil consumption for dump truck at Pit Lisat. These inputs are to decrease the haul road and grade road from front loading to dumping location so as to make fuel oil consumption of operating dump truck at Pit Lisat more efficient.

\section{References}

[1] A. Rahman. 2015. Analisis Dampak Perubahan Harga Bahan Bakar Minyak Dan Batubara Terhadap Pergerakan Harga Saham PT. Indo Tambang Raya Megah, Tbk. Tugas Akhir. Tidak Diterbitkan. Fakultas Teknologi Kebumian dan Energi. Universitas Trisakti: Jakarta

[2] Y. Indonesianto. 2006. Pemindahan Tanah Mekanis. Jurusan Teknik Pertambangan-FTM, UPN Veteran, Yogyakarta.

[3] S. Kurnianto. 2010. Analisis Pengaruh Kemiringan Jalan Dan Jarak Angkut Terhadap Fuel Ratio Pada Kegiatan Pengupasan Overburden Di Pit GaharuKapur, Sambarata Mine Operation, PT. Berau Coal. Skripsi. Tidak Diterbitkan. Fakultas Teknik Pertambangan dan Perminyakan. Institut Teknologi Bandung: Bandung.

[4] Asiyanto. 2008. Manajemen Alat Berat Untuk Konstruksi. Jakarta: Pradnya Paramita.

[5] Z. Bodie, and R. C. Merton. 2000. Finance. New Jersey: Prentice Hall.

[6] C. Golda. 2016. Analisa Konsumsi Bahan Bakar 
Truk Pada Penambangan Material OverBurden Di PT Petrosea, Tbk Site Kideco Jaya Agung. Tugas Akhir. Tidak Diterbitkan, Fakultas Teknologi Kebumian dan Energi. Universitas Trisakti: Jakarta.

[7] P. Prodosumarto. 2000. Pemindahan Tanah Mekanis, Jurusan Teknik Pertambangan ITB.

[8] Jaybridge Robotics, LXD Haul Truck Automation. Diakses pada tanggal 17 Januari 2018 dari http://www.jaybridge.com/solutions /automatedhaul-trucks/
[9] Komatsu. 2007. Komatsu Specifications and Applications Handbook 28th Edition. Komatsu Ltd., Akasaka, Minato-ku, Tokyo, Japan

[10] A. D. Bunayya. 2016. Kajian Konsumsi Bahan Bakar Dalam Proses Pengupasan Lapisan Tanah Penutup Di PT. Adimitra Baratama Nusantara. Tugas Akhir. Tidak Diterbitkan, Fakultas Teknologi Kebumian dan Energi. Universitas Trisakti: Jakarta. 